\title{
Pengaruh Risiko Bisnis, Struktur Aktiva, Ukuran Perusahaan, Dan Pertumbuhan Penjualan Terhadap Struktur Modal
}

\author{
Selvi Yona Sari , Dicky Ramadhani , Yosi Yulia \\ Universitas Putra IndonesiaYPTK Padang, Indonesia \\ Email: Selvi.yona@gmail.com
}

\begin{abstract}
Abstrak
Penelitian ini bertujuan untuk menguji seberapa besar pengaruh risiko bisnis, struktur aktiva, ukuran perusahaan, dan pertumbuhan penjualan terhadap struktur modal. Populasi penelitian ini sebanyak 83 pada sektor aneka industri dan barang konsumsi perusahaan manufaktur yang terdaftar di Bursa Efek Indonesia (BEI) dengan sampel penelitian sebanyak 37 perusahaan selama tahun 2012-2016. Penelitian ini menggunakan metode purposive sampling.Teknik analisis data yang digunakan dalam penelitian ini adalah analisis regresi linear berganda.Dari penelitian ini diperoleh kesimpulan sebagai berikut: variabel risiko bisnis secara parsial berpengaruh signifikan terhadap struktur modal. Struktur aktiva, ukuran perusahaan dan pertumbuhan penjualan secara parsial tidak berpengaruh signifikan terhadap struktur modal. Persamaan regresi yang diperoleh adalah $Y=-1,674-0,255 X_{1}+0,094 X_{2}+0,327 X_{3}+0,089 X_{4}+$ e. Besarnya koefisien determinasi (adjusted $R^{2}$ ) adalah sebesar $6 \%$ yang artinya 0,060 struktur modal dipengaruhi oleh variabel independen, sedangkan sisanya sebesar $94 \%$ diterangkan oleh variabel lain yang tidak diajukan di dalam penelitian.
\end{abstract}

Kata kunci: Struktur Modal, Risiko Bisnis, Struktur Aktiva, Ukuran Perusahaan, Pertumbuhan Penjualan.

\section{Pendahuluan}

Fenomena menunjukkan Garuda telah mend apat komitmen pendanaan $\$ 4,5$ miliar dari BOC Aviation, anak usaha Bank of China. Penandatanganan kesepakatan antara Direktur Utama Garuda M. Arif Wibowo dan Managing Director and CEO BOC Aviation Robert Martin disaksikan langsung oleh Menteri Negara BUMN Rini Soemarno di sela-sela acara Paris Air Show di Le Bourguet, Paris."Garuda sudah bisa mencari pendanaan sendiri," ujar Rini, bangga, 16 Juni.Namun, perlu dicatat bahwa pinjaman ini tak pelak kian menggelembungkan utang Garuda.Sebagaimana diketahui, maskapai pelat merah ini sudah memiliki utang yang cukup besar. Per kuartal I-2015, rasio utang terhadap modal (debt to equity ratio/DER) Garuda sudah mencapai 1,5 kali. Angka ini lebih tinggi dari periode yang sama tahun lalu sebesar 1,1 kali. Jika ditambah utang $\$ 4,5$ miliar ini, maka rasio utang GIAA bakal membengkak sampai 6,65 kali.

Artinya, jika tidak ada suntikan modal baru dari pemegang saham, utang Garuda bisa menyentuh enam kali lipat dari modal perusahaan (equity).Menurut data CSI Market.com, ratarata rasio DER perusahaan penerbangan di Amerika saja hanya empat kali. Walhasil jika DER Garuda mencapai enam kali maka kesehatan secara struktur modal jauh berkurang dan akan membebani keuangan Garuda.

Kesalahan menentukan struktur modal mempunyai dampak luas, terutama bila perusahaan menggunakan hutang yang besar. Beban yang ditanggung perusahaan akan semakin besar, dan meningkatkan risiko finansial, yaitu perusahaan tidak bisa membayarkan beban bunga dan angsuran hutang. Menurut Brigham dan Houston dalam Puspida (2013) menyatakan bahwa risiko bisnis adalah ketidakpastian mengenai proyeksi pengembalian atas aktiva di masa mendatang. Suatu perusahaan mempunyai risiko bisnis yang kecil apabila permintaan akan produknya stabil, harga-harga masukan dan produknya relative konstan, harga produknya dapat segera disesuaikan dengan kenaikan biaya, dan penjualannya menurun. Struktur Aktiva adalah 
faktor yang mempengaruhi pembuatan keputusan struktur modal.Semakin besar struktur aktiva maka semakin besar penggunaan hutang pada struktur modalnya, hal ini menunjukkan bahwa semakin banyak jumlah aktiva tetap yang bisa digunakan sebagai jaminan hutang oleh perusahaan.Sedangkan, makin kecil struktur aktiva yang dimiliki oleh suatu perusahaan, maka semakin kecil pula kemampuan perusahaan tersebut agar dapat menjamin hutang jangka panjang. Ukuran Perusahaan menurut Bambang dalam Putri (2012) semakin besar suatu perusahaan, semakin mudah perusahaan itu memperoleh hutang.Perusahaan besar memiliki kemudahan akses sehingga fleksibilitas perusahaan besar juga lebih besar.

Pertumbuhan penjualan menurut penelitian yang dilakukan oleh Ningsih (2016) mengemukakan bahwa semakin tinggi tingkat pertumbuhan penjualan dan laba yang tinggi memiliki penggunaan hutang sebagai sumber dana eksternal yang lebih besar dibandingkan dengan tingkat pertumbuhan penjualan yang rendah, karena pertumbuhan penjualan yang tinggi akan menunjukkan prospek perusahaan tersebut sedang mengalami peningkatan, yang berarti akan memberikan sinyal ke pihak manajemen ke pasar modal, bahwa manajemen tersebut yakin dengan prospek perusahaan yang bagus akan memberi kepercayaan ke pihak investor untuk memberikan banyak dana eksternal (hutang) kepada manajemen dan dengan peningkatan penjualan tersebut akan mampu membayar pinjamannya.

\section{Struktur Modal}

Menurut Fahmi (2012:184) struktur modal adalah komposis saham biasa, saham preferen, dan berbagai kelas seperti itu, laba ditahan, dan utang jangka panjang yang dipertahankan oleh kesatuan usaha dalam mendanai aktiva.

\section{Risiko Bisnis}

Menurut Fahmi (2015:357) risiko dapat ditafsirkan sebagai bentuk keadaan ketidakpastian tentang suatu keadaan yang akan terjadi nantinya dengan keputusan yang diambil berdasarkan berbagai pertimbangan saat ini.

\section{Struktur Aktiva}

Menurut Bambang (2008:22) struktur aktiva atau struktur kekayaan adalah perimbangan atau perbandingan baik dalam artian absolut maupun dalam artian relatif antara aktiva lancar dengan aktiva tetap.Yang dimaksud dengan artian absolut adalah perbandingan dalam bentuk nominal, sedangkan yang dimaksud dengan artian relatif adalah perbandingan dalam bentuk persentase.

\section{Ukuran Perusahaan}

Menurut Torang (2012:93) ukuran perusahaan dapat diukur dengan menggunakan total aktiva, penjualan, atau modal dari perusahaan tersebut.Ketiga variabel ini digunakan untuk menentukan ukuran perusahaan karena dapat mewakili seberapa besar perusahaan tersebut. Semakin besar aktiva makan semakin banyak modal yang ditanam, semakin banyak penjualan maka semakin banyak pula perputaran uang dan semakin besar pula ia dikenal didalam masyarakat. Besar kecilnya perusahaan dapat diukur dengan total aktiva perusahaan dengan menggunakan perhitungan logaritma natural total aktiva.

\section{Pertumbuhan Penjualan}

Menurut Kasmir (2010:116), rasio pertumbuhan (growth ratio) merupakan rasio yang menggambarkan kemampuan perusahaan mempertahankan posisi ekonominya di tengah pertumbuhan perekonomian dan sector usahanya. Dalam rasio ini, yang di analisis adalah pertumbuhan penjualan, pertumbuhan laba bersih, pertumbuhan pendapatan persaham, dan pertumbuhan deviden persaham. 


\section{Metodologi Penelitian}

Menurut Sanusi (2014:87) sampel adalah bagian dari elemen-elemen populasi.Sampel yang digunakan dalam penelitian ini, diambil berdasarkan purposive sampling method yaitu pengambilan sampel didasarkan pada kriteria-kriteria tertentu.

Sampel yang digunakan adalah sampel yang memenuhi kriteria sebagai berikut :

1. Perusahaan manufaktur sektor aneka industri dan barang konsumsi yang terdaftar di BEI dari tahun 2012- 2016.

2. Perusahaan yang mempublikasikan laporan keuangan secara lengkap selama periode 2012-2016.

3. Perusahaan tidak mengalami kerugian selama periode penelitian yaitu tahun 2012-2016.

4. Perusahaan yang menggunakan mata uang rupiah.

\section{Metode Analisis Data}

\section{Statistik Deskriptif}

Menurut Sugiyono (2014 :147) Statistik deskriptif adalah statistik yang digunakan untuk menganalisis data dengan cara mendeskripsikan atau menggambarkan data yang telah terkumpul sebagaimana adanya tanpa bermaksud membuat kesimpulan yang berlaku untuk umum atau generalisasi.

\section{Uji Asumsi Klasik}

Menurut Lupiyoadi dan Ikhsan (2015:134) Sebelum melakukan analisis regresi perlu dilakukan pengujian asumsi klasik sebelumnya.Hal ini dilakukan agar data sampel yang diolah dapat memberikan informasi yang benar- benar valid dan mewakili populasi secara keseluruhan.

\section{Analisis Regresi Berganda}

Menurut Sugiyono (2014:277) analisis ini untuk meramalkan bagaimana keadaan (naik turunnya) variabel dependen (kriterium), bila dua atau lebih variabel independen sebagai faktor prediktor dimanipulasi (dinaik turunkan nilainya).Jadi analisis regresi linier berganda dilakukan bila jumlah variabel independennya minimal 2. Persamaan regresi linier berganda sebagai berikut Rumus:

Dimana:

$$
Y=a+b_{1} X_{1}+b_{2} X_{2}+b_{3} X_{3}+b_{4} X_{4}+e
$$

$$
\begin{array}{ll}
\mathrm{Y} & =\text { Struktur Modal } \\
\mathrm{X}_{1} & =\text { Risiko Bisnis } \\
\mathrm{X}_{2} & =\text { Struktur Aktiva } \\
\mathrm{X}_{3} & =\text { Ukuran Perusahaan } \\
\mathrm{X}_{4} & =\text { Pertumbuhan Penjualan } \\
\mathrm{a} & =\text { Konstanta } \\
\mathrm{b}_{1}, \mathrm{~b}_{2,}, & =\text { Koefisien regresi masing-masing variabel } \\
\mathrm{e} &
\end{array}
$$

\section{Uji Hipotesis \\ Uji t (parsial)}

Uji-t bertujuan untuk menguji pengaruh secara parsial antara variabel bebas terhadap variabel terikat dengan mengasumsikan variabel variabel lain yang dianggap konstan. Untuk menentukan nilai perbandingan maka dapat dihitung dengan rumus: 
Keterangan:

$$
t_{\text {hitung }}=\frac{r \sqrt{n-2}}{\sqrt{1-r}}
$$

$\mathrm{r}=$ koefisien korelasi

$\mathrm{n}=$ Jumlah anggota sample

a. Jika $t$ hitung lebih besar dari $t$ tabel ( $\mathrm{t}$ hitung $>\mathrm{t}$ tabel), hal ini menunjukkan bahwa variabel bebas mempunyai pengaruh yang signifikan terhadap variabel terikat. Maka : H0 ditolak, H1 diterima.

b. Jika t hitung lebih kecil dari Ttabel (Thitung < Ttabel) hal ini menunjukkan bahwa variabel bebas tidak mempunyai pengaruh yang signifikan terhadap variabel terikat. Maka : H0 diterima, H1 ditolak.

\section{Uji F (Simultan)}

Menurut Sanusi (2014:137) uji F yang signifikan menunjukan bahwa variasi variabel terikat dijelaskan sejian persen variabel bebas secara bersama-sama adalah benar-benar nyata dan bukan terjadi secara kebetulan. Variabel terikat dijelaskan oleh variabel bebas secara bersamasama, dijawab oleh koefisien determinasi $\left(R^{2}\right)$, sedangkan sginifikan atau tidak yang sekian persen dijawab oleh uji F.

Rumus uji F dapat di hitung sebagai berikut:

Keterangan:

$$
F_{\text {hitung }}=\frac{R^{2} / K}{\left(1-R^{2}\right) /[n-(k+1)]}
$$

$R^{2}=$ Koefisien determinasi

$\mathrm{n}=$ Jumlah sampel

$\mathrm{k}=$ Jumlah vaiabel yang digunakan

\section{Uji Koefisien Determinasi $\left(\mathbf{R}^{2}\right)$}

Menurut Sanusi (2014:136) koefisien determinasi $\left(R^{2}\right)$ menjelaskan proporsi variasi dalam variabel terikat $(\mathrm{Y})$ yang dijelaskan oleh variabel bebas (lebih dari satu variabel ;X;i=1,2,3...,k) secara bersama-sama. $r^{2}$ mengukur kebaikan-sesuai (good-of-fit) dari persamaan regresi, yaitu memberikan persentase variasi total dalam variabel terikat (Y) yang dijelaskan oleh hanya satu variabel bebas $(\mathrm{X}) . \mathrm{r}$ adalah koefisien korelasi yang menjelaskan keeratan hubungan linear diantara dua variabel, nilai nya dapat negatif dan positif

\section{Hasil Dan Pembahasan}

\section{Statistik Deskriptif}

Tabel 1. Hasil Analisa Deskriptif Descriptive Statistics

\begin{tabular}{|l|r|r|r|r|r|}
\hline & \multicolumn{1}{|c|}{$\mathrm{N}$} & Minimum & Maximum & \multicolumn{1}{c|}{ Mean } & Std. Deviation \\
\hline SM & 185 & .10 & 7.44 & .9138 & .82142 \\
RB & 185 & .02 & 2.46 & .1577 & .20148 \\
SA & 185 & .13 & 1.25 & .4156 & .17236 \\
UP & 185 & 25.51 & 33.20 & 28.5493 & 1.66194 \\
PP & 185 & -.73 & 4.99 & .1430 & .40149 \\
Valid N & 185 & & & & \\
(listwise) & & & & & \\
\hline
\end{tabular}

Sumber : Hasil Pengolahan dengan SPSS 23 
Dari Tabel 1 dijelaskan bahwa jumlah data (n) adalah 185.Untuk variabel Struktur Modal (Y)nilai maksimum sebesar7,44, nilai minimum sebesar 0,10 , nilai mean 0,9138 , dengan standar deviasi 0,82142. Pada variabel Risiko Bisnis (X1) nilai maksimumnya adalah 2,46, nilai minimumnya sebesar 0,02 , nilai mean 0,1577 , dengan standar deviasi 0,20148 . Pada variabel Struktur Aktiva (X2) nilai maksimum sebesar 1,25, nilai minimum sebesar 0,13, nilai mean 0,4156, dengan standar deviasi 0,17236. Pada variabel Ukuran Perusahaan (X3) nilai maksimumnya adalah 33,20, nilai minimumnya sebesar 25,51, nilai mean 28,5493, dengan standar deviasi 1,66194. Pada variabel Pertumbuhan Penjualan (X4) nilai maksimumnya sebesar 4,99, nilai minimumnya sebesar $-0,73$, nilai mean 0,1430 , dengan standar deviasi 0,40149 .

\section{Asumsi Klasik}

\section{Uji Normalitas}

Tabel 2. One-Sample Kolmogorov-Smirnov Test

\begin{tabular}{|l|l|r|}
\hline \multicolumn{2}{|l|}{} & $\begin{array}{c}\text { Unstandardize } \\
\text { d Residual }\end{array}$ \\
\hline $\mathrm{N}$ & Mean & 158 \\
\cline { 2 - 3 } Normal Parameters & Std. Deviation & .0000000 \\
\hline \multirow{2}{*}{ Most Extreme Differences } & Absolute & .056 \\
\cline { 2 - 3 } & Positive & .056 \\
\cline { 2 - 3 } & Negative & -.040 \\
\hline Test Statistic & .056 \\
\hline Asymp. Sig. (2-tailed) & $.200^{\mathrm{c}, \mathrm{d}}$ \\
\hline
\end{tabular}

Sumber : Hasil Pengolahan dengan SPSS 23

Berdasarkan tabel diatas uji normalitas dengan menggunakan uji One-Sample KolmpgrovSmirnov, terlihat bahwa nilai Kolmpgrov-Smirnov untuk Asymp. Sig. (2-tailed) sebesar0,200 diatas 0,05 . Hal ini mengindikasikan bahwa data residual terdistribusi normal.

\section{Uji Multikolineritas}

Tabel 3. Hasil Uji Multikolonieritas

\section{Coefficients $^{\mathrm{a}}$}

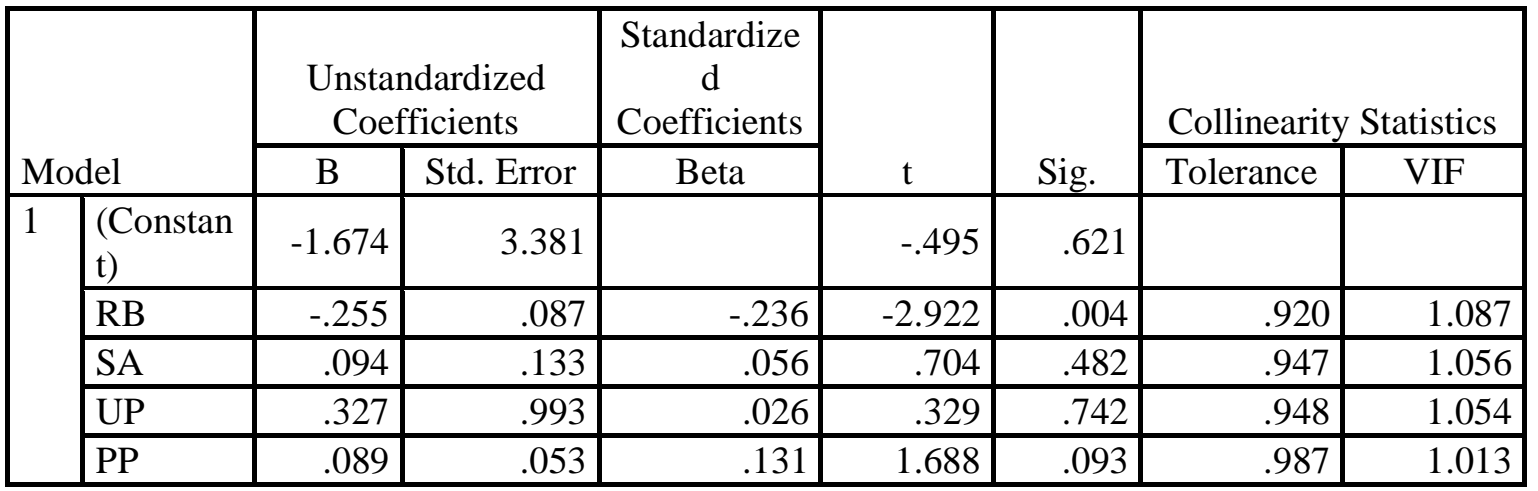

Sumber : Hasil Pengolahan dengan SPSS 23

Tabel diatas menunjukkan bahwa semua variabel independen (risiko bisnis, struktur aktiva, ukuran perusahaan, dan pertumbuhan penjualan) mempunyai nilai VIF kurang dari 10 dan nilai tolerance lebih dari 0,10 . Hal ini mengindikasikan bahwa model ini terbebas dari masalah multikoloniearitas. 


\section{Uji Autokorelasi}

Tabel 4. Hasil Uji Autokorelasi Model Summary ${ }^{b}$

\begin{tabular}{|l|r|r|r|r|r|}
\hline Model & \multicolumn{1}{|c|}{$\mathrm{R}$} & R Square & $\begin{array}{c}\text { Adjusted R } \\
\text { Square }\end{array}$ & $\begin{array}{l}\text { Std. Error of } \\
\text { the Estimate }\end{array}$ & $\begin{array}{c}\text { Durbin- } \\
\text { Watson }\end{array}$ \\
\hline 1 & $.290^{\mathrm{a}}$ & .084 & .060 & .68292 & .759 \\
\hline
\end{tabular}

Sumber : Hasil Pengolahan dengan SPSS 23

Dari Tabel 4 terlihat bahwa angka D-W yang diperoleh yaitu 0,759.Angka tersebut terletak di antara -2 sampai +2.Ini berarti bahwa pada model regresi terbebas dari masalah autokorelasi.

\section{Uji Heteroskedastisitas}

Uji heteroskedastisitas bertujuan untuk menguji apakah dalam model regresi terjadi ketidaksamaan variance dan residual satu pengamatan ke pengamatan yang lain.

\section{Hasil Uji Heteroskedastisita}

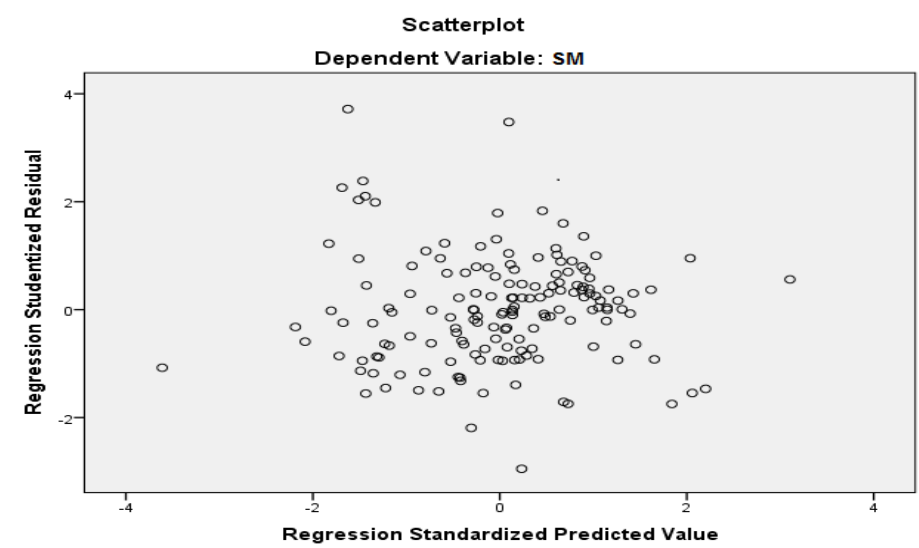

\section{Sumber : Hasil Pengolahan dengan SPSS 23}

\section{Gambar 1. Scatterplot}

Dari gambar di atas, dapat dilihat titik-titik menyebar secara acak dan tidak membentuk suatu pola tertentu, serta tersebar di atas dan di bawah angka 0 pada sumbu Y. untuk memperkuat, maka didukung dengan uji glejser, dengan hasil seperti tabel dibawah ini :

\section{Hasi Uji Glejser}

Tabel 5 Coefficients ${ }^{\mathrm{a}}$

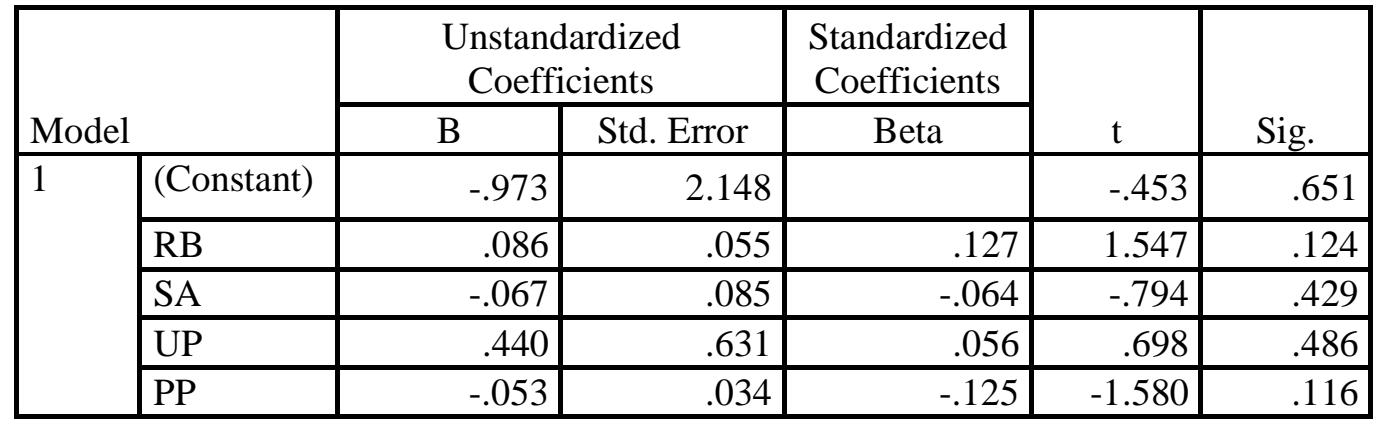

Sumber : Hasil Pengolahan dengan SPSS 23 
Dari tabel diatas dapat dilihat setiap variabel indepeden(risiko bisnis, struktur aktiva, ukuran perusahaan, dan pertumbuhan penjualan)memiliki nilai signifikan diatas 0,05 . Maka model ini terbebas dari masalah heteroskedastisitas. Sehingga model regresi ini dapat digunakan untuk menganalisis pengaruh risiko bisnis, struktur aktiva, ukuran perusahaan, dan pertumbuhan penjualanterhadap struktur modal.

\section{Analisis Regresi Linier Berganda}

Tabel 6.

Hasil Analisis Regresi Linier Berganda Variabel Risiko Bisnis $\left(\mathbf{X}_{1}\right)$, Struktur Aktiva $\left(\mathbf{X}_{2}\right)$, Ukuran Perusahaan $\left(\mathbf{X}_{3}\right)$, Pertumbuhan Penjualan $\left(\mathbf{X}_{4}\right)$ Terhadap Struktur Modal $(\mathbf{Y})$

Coefficients $^{\mathrm{a}}$

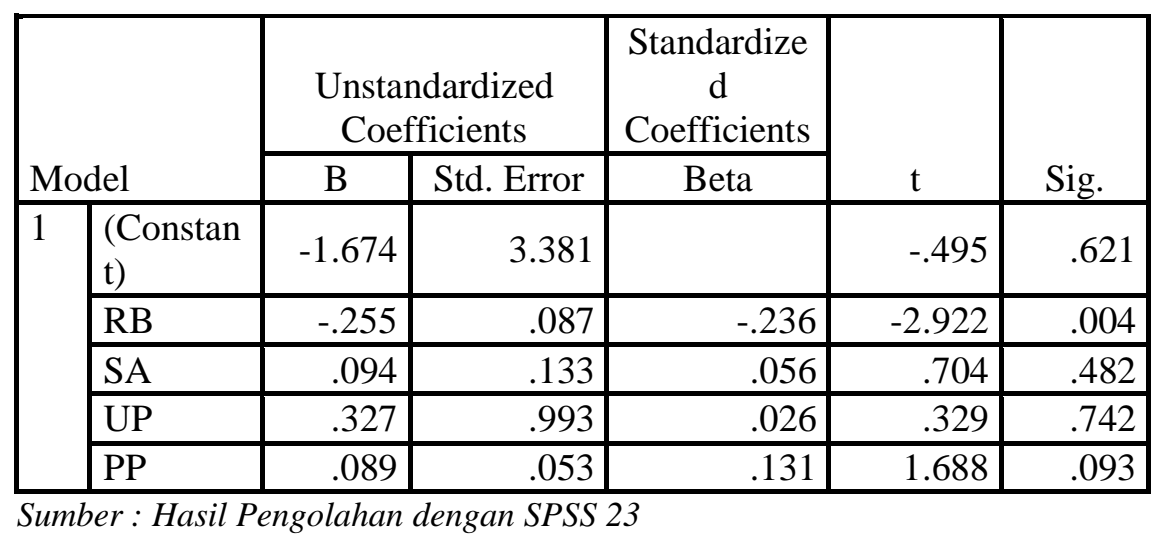

Berdasarkan tabel diatas maka dapat dilihat persamaan regresinya yaitu :

$$
Y=-1,674-0,255 X_{1}+0,094 X_{2}+0,327 X_{3}+0,089 X_{4}+e
$$

Dari persamaan regresi berganda di atas dapat disimpulkan bahwa :

1) Nilai konstanta sebesar -1,674; artinya risiko bisnis $\left(X_{1}\right)$, struktur aktiva $\left(X_{2}\right)$, ukuran perusahaan $\left(X_{3}\right)$ dan pertumbuhan penjualan $\left(X_{4}\right)$, diabaikan $(0)$, maka struktur modal (Y) nilainya adalah sebesar $\mathbf{- 1 , 6 7 4}$

2) Koefisien regresi variabel risiko bisnis $\left(X_{1}\right)$ sebesar - 0,255; jika risiko bisnis $\left(X_{1}\right)$ mengalami peningkatan satu (1) satuan bobot dengan asumsi struktur aktiva $\left(\mathrm{X}_{2}\right)$,ukuran perusahaan $\left(\mathrm{X}_{3}\right)$ dan pertumbuhan penjualan $\left(\mathrm{X}_{4}\right)$ diabaikan (0) maka struktur modal (Y) akan mengalami penurunan sebesar $\mathbf{0 , 2 5 5}$.

3) Koefisien regresi variabel struktur aktiva $\left(X_{2}\right)$ sebesar $\mathbf{0 , 0 9 4}$; jika struktur aktiva $\left(\mathrm{X}_{2}\right)$ mengalami peningkatan satu (1) satuan bobot dengan asumsi risiko bisnis $\left(\mathrm{X}_{1}\right)$, ukuran perusahaan $\left(\mathrm{X}_{3}\right)$, dan pertumbuhan penjualan $\left(\mathrm{X}_{4}\right)$ diabaikan $(0)$ maka struktur modal (Y) akan mengalami peningkatan sebesar $\mathbf{0 , 0 9 4}$.

4) Koefisien regresi variabel ukuran perusahaan $\left(X_{3}\right)$ sebesar $\mathbf{0 , 3 2 7}$; jika ukuran perusahaan $\left(\mathrm{X}_{3}\right)$ mengalami peningkatan satu (1) satuan bobot dengan asumsi risiko bisnis $\left(\mathrm{X}_{1}\right)$, struktur aktiva $\left(\mathrm{X}_{2}\right)$, dan pertumbuhan penjualan $\left(\mathrm{X}_{4}\right)(0)$ maka struktur modal (Y) akan mengalami peningkatan sebesar $\mathbf{0 , 3 2 7}$.

5) Koefisien regresi variabel pertumbuhan penjualan $\left(\mathrm{X}_{4}\right)$ sebesar $\mathbf{0 , 0 8 9}$; jika pertumbuhan penjualan $\left(\mathrm{X}_{4}\right)$ mengalami peningkatan satu (1) satuan bobot dengan asumsi risiko bisnis $\left(\mathrm{X}_{1}\right)$, struktur aktiva $\left(\mathrm{X}_{2}\right)$, dan ukuran perusahaan $\left(\mathrm{X}_{3}\right)$ diabaikan (0) maka struktur modal (Y) akan mengalami peningkatan sebesar 0,089 . 
Tabel 7 Hasil Pengujian Secara Parsial Atas Semua Variabel Independen Coefficients $^{\mathrm{a}}$

\begin{tabular}{|c|c|c|c|c|c|c|}
\hline \multirow{2}{*}{\multicolumn{2}{|c|}{ Model }} & \multicolumn{2}{|c|}{$\begin{array}{c}\text { Unstandardized } \\
\text { Coefficients }\end{array}$} & \multirow{2}{*}{$\begin{array}{c}\begin{array}{c}\text { Standardize } \\
\mathrm{d} \\
\text { Coefficients }\end{array} \\
\text { Beta }\end{array}$} & \multirow[b]{2}{*}{$\mathrm{t}$} & \multirow[b]{2}{*}{ Sig. } \\
\hline & & $\mathrm{B}$ & Std. Error & & & \\
\hline \multirow[t]{5}{*}{1} & \begin{tabular}{|l} 
(Constan \\
t) \\
\end{tabular} & -1.674 & 3.381 & & -.495 & .621 \\
\hline & $\mathrm{RB}$ & -.255 & .087 & -.236 & -2.922 & .004 \\
\hline & \begin{tabular}{|l|} 
SA \\
\end{tabular} & .094 & .133 & .056 & .704 & .482 \\
\hline & $\overline{U P}$ & .327 & .993 & .026 & .329 & .742 \\
\hline & PP & .089 & .053 & .131 & 1.688 & .093 \\
\hline
\end{tabular}

Sumber : Hasil Pengolahan dengan SPSS 23

Berdasarkan tabel di atas maka dapat disimpulkan sebagai berikut :

\section{a. Pengaruh Risiko Bisnis Terhadap Struktur Modal}

Dari tabel diatas di ketahui $\mathrm{t}$ hitung $<\mathrm{t}$ tabel $(-2,922<1,97331)$ dengan tingkat siginifikan $(0,004<0,05)$, artinya secara parsial terdapat pengaruhsignifikan antara risiko bisnis terhadapstruktur modal. Dengan demikian Ho ditolak dan Ha diterima.

Ho: Jika thitung $<\mathrm{t}$ tabel $(\alpha=0,05)$, maka Ho diterima, artinya tidak ada pengaruh antara risiko bisnis secara parsial terhadap struktur modal.

Ha: Jika $\mathrm{t}$ hitung $>\mathrm{t}$ tabel $(\alpha=0,05)$, maka Ha diterima, artinya ada pengaruh antara risiko bisnis secara parsial terhadap struktur modal.

b. Pengaruh Struktur Aktiva Terhadap Struktur Modal

Dari tabel diatas di ketahui $\mathrm{t}$ hitung $<\mathrm{t}$ tabel $(0,704<1,97331)$ dengan tingkat siginifikan $(0,482>0,05)$, artinya secara parsial tidak terdapat pengaruhsignifikan antara struktur aktiva terhadapstruktur modal. Dengan demikian Ho diterima dan Ha ditolak.

Ho: Jika t hitung $<\mathrm{t}$ tabel $(\alpha=0,05)$, maka Ho diterima, artinya tidak ada pengaruh antara struktur aktiva secara parsial terhadap struktur modal.

Ha: Jika t hitung $>\mathrm{t}$ tabel $(\alpha=0,05)$, maka Ha diterima, artinya ada pengaruh antara struktur aktiva secara parsial terhadap struktur modal.

\section{c. Pengaruh Ukuran PerusahaanTerhadap Struktur Modal}

Dari tabel diatas di ketahui $t$ hitung $<\mathrm{t}$ tabel $(0,329<1,97331)$ dengan tingkat siginifikan $(0,742>0,05)$, artinya secara parsial tidakterdapat pengaruh signifikan antara ukuran perusahaan terhadapstruktur modal. Dengan demikian Ho diterima dan Ha ditolak.

Ho: Jika t hitung $<\mathrm{t}$ tabel $(\alpha=0,05)$, maka Ho diterima, artinya tidak ada pengaruh antara ukuran perusahaan secara parsial terhadap struktur modal.

Ha: Jika t hitung $>\mathrm{t}$ tabel $(\alpha=0,05)$, maka Ha diterima, artinya ada pengaruh antara ukuran perusahaan secara parsial terhadap struktur modal.

\section{d. Pengaruh Pertumbuhan PenjualanTerhadap Struktur Modal}

Dari tabel diatas di ketahui t hitung $<\mathrm{t}$ tabel $(1,688<1,97331)$ dengan tingkat siginifikan $(0,093>0,05)$, artinya secara parsial tidakterdapat pengaruh signifikan antara pertumbuhan penjualan terhadapstruktur modal. Dengan demikian Ho diterima dan $\mathrm{Ha}$ ditolak.

Ho: Jika $\mathrm{t}$ hitung $<\mathrm{t}$ tabel $(\alpha=0,05)$, maka Ho diterima, artinya tidak ada pengaruh antara pertumbuhan penjualan secara parsial terhadap struktur modal.

Ha: Jika t hitung $>\mathrm{t}$ tabel $(\alpha=0,05)$, maka Ha diterima, artinya ada pengaruh antara pertumbuhan penjuala secara parsial terhadap struktur modal. 
Uji F

Tabel 8. Pengujian Hipotesis Semua Variabel Secara Simultan ANOVA ${ }^{\mathrm{a}}$

\begin{tabular}{|l|l|r|r|r|r|r|}
\hline \multicolumn{2}{|l|}{ Model } & \multicolumn{1}{c|}{$\begin{array}{c}\text { Sum of } \\
\text { Squares }\end{array}$} & df & Mean Square & F & Sig. \\
\hline \multirow{3}{*}{1} & Regression & 6.576 & 4 & 1.644 & 3.525 & $.009^{\mathrm{b}}$ \\
\cline { 2 - 7 } & Residual & 71.356 & 153 & .466 & & \\
\cline { 2 - 7 } & Total & 77.932 & 157 & & & \\
\hline
\end{tabular}

Sumber : Hasil Pengolahan dengan SPSS 23

Berdasarkan tabel diatas didapatkan sig yaitu $0,009<0,05$ angka ini menunjukkan $\mathrm{F}_{\text {hitung }} 3,525>\mathrm{F}_{\text {tabel }} 2,42$ maka penulis berkesimpulan berkesimpulan risiko bisnis $\left(\mathrm{X}_{1}\right)$, struktur aktiva $\left(\mathrm{X}_{2}\right)$,ukuran perusahaan $\left(\mathrm{X}_{3}\right)$, dan pertumbuhan penjualan $\left(\mathrm{X}_{4}\right)$ mempunyai pengaruh yang signifikan secara simultan terhadap struktur modal $(\mathrm{Y})$. Dengan demikian Ho ditolak dan Ha diterima.

\section{Kesimpulan}

Setelah dilakukan penelitian sederhana terhadap 37 perusahaan manufaktur sektor aneka industri dan barang konsumsiyang tercatat di Bursa Efek Indonesia selama lima tahun (20122016), maka hasil uraian tentang pengaruh risiko bisnis, struktur aktiva, ukuran perusahaan dna pertumbuhna penjualan terhadap struktur modal dapat disumpulkan sebagai berikut :

1. Terdapat pengaruh negatif dan signifikan antara risiko bisnis secara parsial terhadap strukur modal pada perusahaan manufaktur sektor aneka industri dan barang konsumsi yang tercatat di Bursa Efek Indonesia periode 2012-2016.

2. Tidak terdapat pengaruh positif dan signifikan antara struktur aktiva secara parsial terhadap strukur modal pada perusahaan manufaktur sektor aneka industri dan barang konsumsi yang tercatat di Bursa Efek Indonesia periode 2012-2016.

3. Tidak terdapat pengaruh positif dan signifikan antara ukuran perusahaan secara parsial terhadap strukur modal pada perusahaan manufaktur sektor aneka industri dan barang konsumsi yang tercatat di Bursa Efek Indonesia periode 2012-2016.

4. Tidak terdapat pengaruh positf dan signifikan antara pertumbuhan penjualan secara parsial terhadap strukur modal pada perusahaan manufaktur sektor aneka industri dan barang konsumsi yang tercatat di Bursa Efek Indonesia periode 2012-2016.

5. Terdapat pengaruh positif dan signifikan antara risiko bisnis, struktur aktiva, ukuran perusahaan dan pertumbuhan penjualan secara simultan terhadap struktur modal pada perusahaan manufaktur sektor aneka industri dan barang konsumsi.

6. Diperoleh Adjust R Square sebesar 0,060 hal ini menunjukkan bahwa kontribusi variabel risiko bisnis, struktur aktiva, ukuran perusahaan, dan pertumbuhan penjualan terhadap struktur modal hanyak sebesar 0,060 atau 6\% sedangkan sisanya $94 \%$ ditemukan oleh variabel lain yang tidak dianalisis dalam penelitian ini. 


\section{DAFTAR PUSTAKA}

[1]Asnawi, Said Kelana dan Chandra Wijaya. 2015. Finon (Finance for non finance) manajemen keuangan untuk non keuangan: Menjadi tahu dan lebih tahu. Jakarta. PT RajaGrafindo Persada.

[2]Atmaja, L.S. 2008. Teori dan Praktik Manajemen Keuangan. Yogyakarta: CU Andi Offset.

[3]Bambang, Riyanto. 2008. Dasar-dasar pembelanjaan perusahaan. Yogyakarta:BPFE.

[4]Brigham dan Houston. 2011. Dasar-dasar Manajemen Keuangan. Edisi Kesebelas. Jakarta: Salemba Empat.

[5]Fahmi, Irham. 2012. Analisis Laporan Keuangan. Bandung: Alfabeta.

[6]Fahmi, Irham. 2014. Analisis Laporan Keuangan. Bandung: Alfabeta.

[7]Fahmi, Irham. 2014. Mananjemen Keuangan Perusahaan dan Pasar Modal. Jakarta: Mitra Wicana Media.

[8]Fahmi, Irham. 2015. Pengantar manajemen keuangan. Bandung: Alfabeta.

[9]Farisa, Nurul Anggun dan Listyorini Wahyu Widati. 2017. Analisa Profitabilitas, Likuiditas, Pertumbuhan Penjualan, Struktur Aktiva dan Kebijakan Deviden Terhadap Struktur Modal. Jurnal. Universitas Stikubank.

[10]Ghozali, Imam. 2016. Aplikasi Analisis Multivariate dengan Program IBM SPSS 21. Semarang: Badan Penerbit Universitas Diponegoro.

[11]Indrajaya, Glenn, dkk. 2011. Pengaruh Struktur Aktiva, Ukuran Perusahaan, Tingkat Pertumbuhan, Profitabilitas dan Risiko Bisnis Terhadap Struktur Modal: Studi Empiris Pada Perusahaan Sektor Pertambangan yang Listing di Bursa Efek Indonesia Periode 2004-2007.Jurnal Ilmiah Akuntansi Nomor 06.

[12]Iqbal, Muhammad. 2015. Pengaruh profitabilitas, likuiditas, pertumbuhan penjualan, ukuran perusahaan dan struktur aset terhadap struktur modal pada perusahaan otomotif yang terdaftar di BEI. Skripsi.Universitas Sumatra Utara.

[13]Kasmir. 2010. Pengantar Manajemen Keuangan. Jakarta. Kencana.

[14]Kurniawan, Galih Dwi. 2013. Pengaruh likuiditas, ukuran perusahaan, pertumbuhan penjualan, dan profitabilitas terhadap struktur modal. Skripsi.Universitas Negeri Yogyakarta.

[15]Laily, Nurul. 2013. Pengaruh tangibility, pertumbuhan penjualan, profitabilitas dan ukuran perusahaan terhadap struktur modal dan harga saham perusahaan. Skripsi.Universitas Islam Negeri Sunan Kalijaga.

[16]Lupiyoadi, Rambat dan Ridho Bramulya Ikhsan. 2015. Pratikum Metode Riset Bisnis. Jakarta : Salemba Empat.

[17]Mandalika, A. 2016.Pengaruh Struktur Aktiva, Struktur Modal, dan Pertumbuhan Penjualan terhadap Nilai perusahaan pada Perusahaan Publik yang Terdaftar di Bursa Efek Indonesia (studi pada sektor otomotif).Jurnal berkala ilmiah efisiensi 16 (1).

[18]Minguela-Rata, Beatriz, et al. 2013. Cooperation with suppliers, firm size and product innovation. Vol. 114 Issue: 3 pp.438-455.

[19]Mulyawan, S. 2015. Manajemen keuangan. Bandung:Pusaka Setia. 